\title{
University Towns: Emerging Sector in India
}

\author{
Kala Choyimanikandiyil
}

\begin{abstract}
According to U.S. Department of Commerce, U.S. Census Bureau, University City are those cities or metropolitan statistical area where total population is between 2,50,000 and one million, out of which minimum $10 \%$ should be the student population. Meanwhile college towns are where students do not continue to settle in that locality unlike University Cities where students find an employment and continue staying.

Articles show that no relevant or successful University cities exist in India so far. Nonetheless there are a lot of Urban Outgrowths like college/university towns which have developed in India over the years that have made an impact in the growth of town locally in various sectors. The author tries to make an attempt to look at the effects of existence of University in the population and the growth of nearby public places through observations of an Indian town incorporating the knowledge of existing research in the field available globally.
\end{abstract}

Keywords-University City, University Towns, College Towns, Community, Indian Scenario, Manipal.

\section{INTRODUCTION}

Population of a university town can be broadly classified as student population and non-student population. Normally colleges create positive impact in the development of local community and thereby increases the human capital of that particular town [1]. In a recent study conducted on the economics of a College Town by comparing two American College towns to three other non-college towns, it was found that the average wage and salary in college towns is very much higher than the other two non-college towns [2]. In India, the scenario is slightly different as the country is still developing as well as the culture of the country is drastically different. None of the towns or cities in India have grown into a niche of job market merely due to the existence of educational institutions. Nonetheless, a university town in India always becomes a land of booming real estate [3].

This paper is an attempt to look at the university towns in India by comparing with other types of towns depending on its growth and development. Another factor enlisted is the effect of presence of university and its precincts on the residing population. The hike in property value in a university town has been studied. The general trend of the population in university has been observed to see their satisfaction level.

\section{DEVELOPMENT OF UNIVERSITY SYSTEM}

\section{A. Evolution}

The University established in Bologna in $1088 \mathrm{AD}$ is considered as the first European University. University at Oxford started in $12^{\text {th }}$ century. University founded in Berlin is the first known research university[4].

Revised Manuscript Received on April 12, 2019.

Kala Choyimanikandiyil, Manipal School of Architecture \& Planning, Manipal Academy of Higher Education, Manipal, India. (E-mail: kala.cmk@manipal.edu) https://orcid.org/0000-0003-4162-5069
The present University of Alcala in Spain claims to be the first University town in the Europe and the Americas which originated in 1293. The University and its historic precinct has been listed as one of the world heritage site in UNESCO [5].

India possess a remarkable history in the educational system. In the first century A. D. itself India already had many centers of learning located in various parts and those were named as Nalanda, Vikramashila, Takshashila, Vallabhi and Kanchipuram [4].

\section{B. University Systems in India}

In the year 1620, the first university established in India was at Bandora in North Goa. This existed till 1739. Later in 1830 the first formal educational institution called Elphinstone College in Bombay was founded by the British During the same time universities were founded in Bombay, Madras and Calcutta.

After a series of development University grants Committee was established in 1945 which in the beginning administered the central universities at Benaras, Aligarh and Delhi. Later in the year 1948, University Commission was formed which led to the establishment of several rural universities [4].

\section{UNIVERSITY - CATALIST FOR THE GROWTH OF TOWNS IN INDIA}

\section{A. Classification of Towns}

According to Census of India 2011, there are some terms defined for towns depending on various criteria. Regions which possess a municipality, corporation, cantonment boards or notified town area committee are termed as Statutory Towns. These are not categorized based on demographic considerations.

Meanwhile Census Towns are those having population of more than 5000 in number and population density of more than 400 persons per sq. $\mathrm{km}$.

Any University Campus located with proper boundaries in a village or hamlet near a statutory town with proper amenities of pucca roads, electricity, water supply and sanitation facilities, post office, bank, medical facilities comes under the category of Out Growths. This should be physically contiguous with the core town of Urban Agglomeration (UA) [6].

\section{B. Distinction between Town and City}

According to Census Department of India, Class I Urban Agglomeration/Towns have population of at least 100,000 persons. Million plus UAs/Towns has population of one million or above. In India, Statutory Towns, Census towns

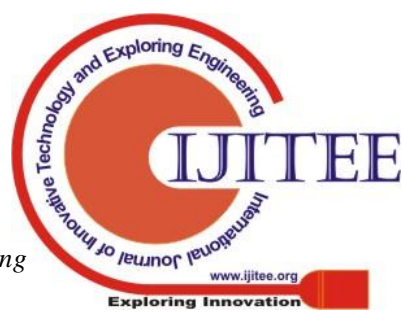


and Outgrowths constitute an Urban Area. India has three megacities which has more than 10 million population such as greater Mumbai, Delhi and Kolkota according to 2011 Census [6].

\section{Growth of Towns in University Premise}

The factors for expansion of University town are population growth and increased intake of student population. Population dwelling in the university town depend some way or the other on the university not only through education but also through public services, most of the times with partnerships through government authorities [7]. More number of restaurants and shopping malls come up in university towns. Pharmaceutical shops, Sports shops, service centers for electronics are all essential components of a university town.

\section{Built and Unbuilt Development in University Towns}

University generates employment in its town and thereby housing, and other related infrastructure, leisure and consumer activities which in turn is provided with all kinds of services such as water supply, sanitation, electricity, accessibility etc. [8]. Schools, Banks, Hospitals, Post office, Police Station, Transportation hubs, Logistic services, etc. are also integral part of any university towns. There is a rapid growth of built environment in the nearby town of university which eventually leads to the growth of university towns.

\section{PUBLIC PLACES IN URBAN DENSIFICATION}

\section{A. Importance of Public Place}

According to Jan Gehl, public spaces have been characterized by inspiration and stimulation with presence of people, activities and events happening in it. Public spaces give opportunity for people to mingle with each other and also to understand about various things happening around the world through observation [9]. Streets, Plazas, Parks and all other available public spaces like schools, clinics, banks, post office, police station etc. constitute a city along with all the required service facilities.

\section{B. Significant Sprawl of Public Place in University Towns}

University towns have three types of public spaces which are publicly owned, university-owned or privately owned [10]. Even though studentification in the town of university creates a lot of disorder such as loud parties, loitering etc., the region keeps growing by the constant sprawl of built spaces away from the periphery [11].

\section{COLLEGE TOWNS - INDIAN SCENARIO}

\section{A. Existing College Towns in India}

By the establishment of private universities and deemed universities in India, there created a lot of Urban Outgrowths due to the development in the precincts of university. By the beginning of $21^{\text {st }}$ century, many college towns were growing as university towns in India, examples of which are Manipal at Karnataka State, Pilani at Rajasthan State, Vellore at Tamilnadu state etc.

The facilities of the town are comparatively superior than other satellite towns because the overall community in university towns create a promising trends in lifestyle and they partner in all kinds of commercial Activities.

\section{B. Economic Growth induced by College Towns in India}

It is an established fact that universities in India promotes social and economic growth of the region [12]. Multifaceted culture coined with innovation driven economies, facilitate the university town to grow at a fast pace [13]. Every piece of real estate in the university towns is always at its peak value compared to its nearby regions. But it is worth paying that amount due to the promising returns resulted by continued growth.

\section{BRIEF STUDY ON MANIPAL \& RESULTS}

\section{A. Introduction of the Region}

Manipal lies in Udupi district in Karnataka State in South India. Manipal is a hillock, $60 \mathrm{~km}$ away from Mangalore city, a known University town due to the existence of deemed university named as Manipal Academy of Higher Education (MAHE). Manipal is easily accessible through highways; has the nearest airport at Mangalore and nearest railway station at $3 \mathrm{~km}$. away from Manipal.

The origin of the university started in 1953 by the establishment of Kasthurba Medical College. After that many other institutions came up under the same management in Manipal. After so many years of development the deemed University MAHE was formed in the year 1993. The University extends over a land of 600 acres approximately [14].

The name Manipal was given to that region due to the lake in that locality called 'Mannupalla'. The region, Manipal, previously belonged to many villages such as Shivalli, Saralabettu, Badagabettu etc. The University building situates in Udupi City Municipal Council which was previously included in Shivalli grama panchayat (village). Manipal is located between North latitudes $13^{\circ}$ $19^{\prime} 11^{\prime \prime}$ and $13^{\circ} 22^{\prime} 37.24^{\prime \prime}$ and East longitudes $74^{\circ} 47^{\prime} 24.88^{\prime \prime}$ and $74^{\circ} 47^{\prime} 37.54^{\prime \prime}$.

The Fig.1 [15] shows the location of Karnataka State in South India and the blown up map of Karnataka State with various districts.

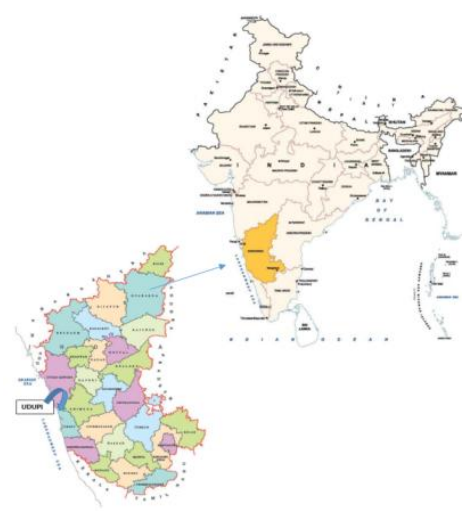

Fig. 1. Location of Karnataka State on India Map \& Karnataka Map highlighted with Districts [Source: Census Dept. of India] 
The Fig. 2. [15] shows the map of Udupi District with enlarged map of Udupi Taluk on the side in which all the campus buildings of MAHE situate.

The Fig. 3. [16] is the map of Manipal, the part of which lies in Udupi City Municipal Council (which was included in Shivalli village earlier) and the remaining part in a few other villages. The satellite map of Manipal shows the growth of town with more built up area and vegetation cleared off.

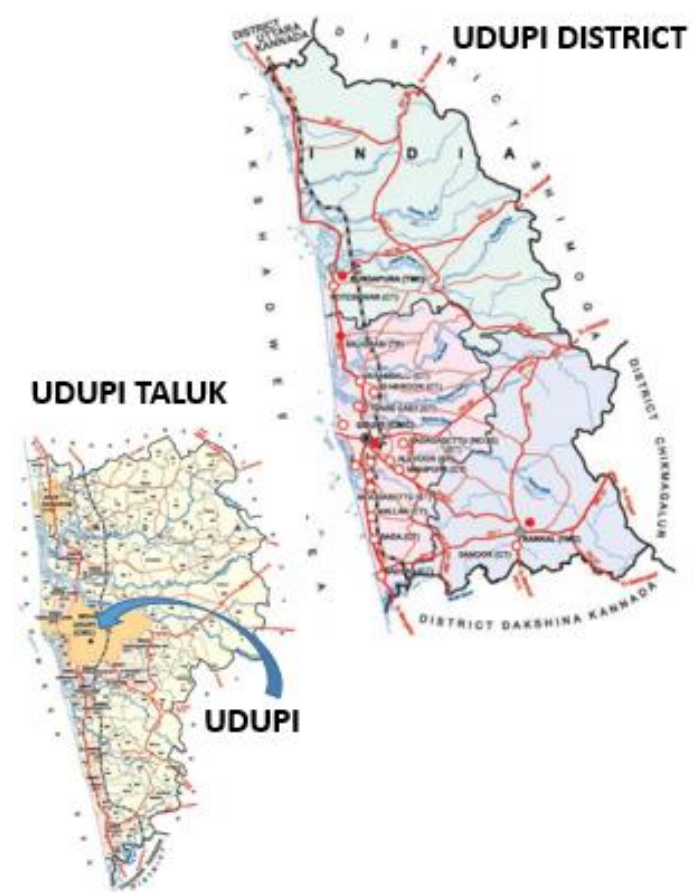

Fig. 2. Map of Udupi District and enlarged map of Udupi Taluk [Source: Census Dept. of India]

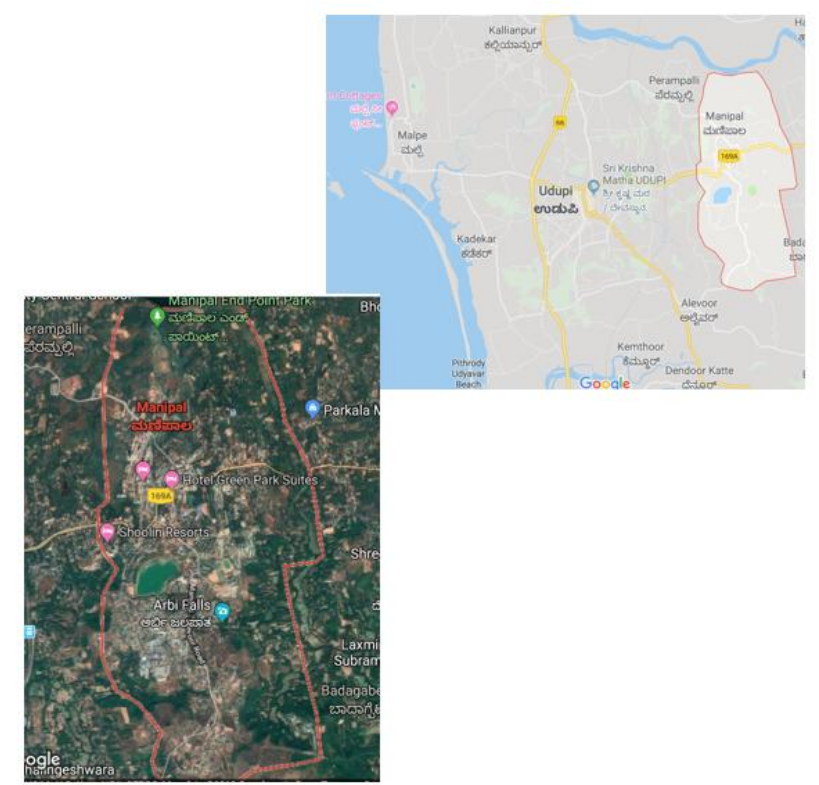

Fig. 3. Location map and satellite map of Manipal [Source: Google maps]

\section{B. Expanse of the University}

Students from almost 57 countries have enrolled at MAHE. The university have over 25 institutions in almost 20 main disciplines. MAHE is considered to be the largest foreign exchange earner of the country in its category.
MAHE which was known as Manipal University is the first educational institution in the private sector to be established as deemed university [17].

The total number of students enrolled in the academic year 2018-2019, is 33,411 whereas student intake in the same year is 15,522 . The employees working in the university is around 12,410 . The total number of alumni is 168595 [18]. This shows that the increase in the number of student intake is very rapid. This is one of the facts that causes the rapid growth of the city.

\section{Comparison of Manipal with nearby towns}

Fig. 4 compares the Google Earth maps of Manipal region in the year 2019 and 2004 which shows the excessive development of built up land cover [19].
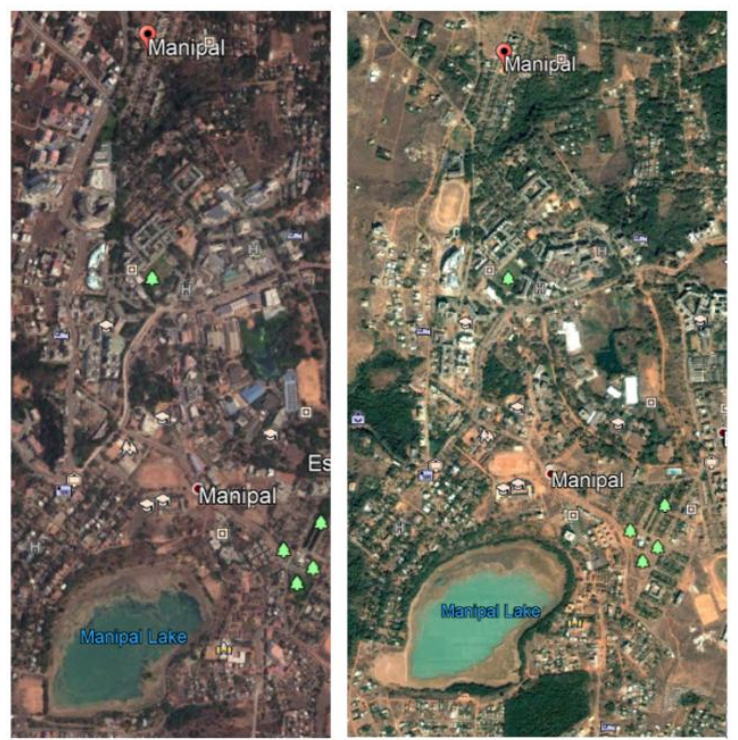

Fig. 4. Satellite Map of Manipal region in the year 2019(left) and 2004 (right)

Parkala is the name of the adjacent upcoming village to the east of Manipal $4 \mathrm{~km}$. away and connected by UdupiKarkala Highway. Very recently students from Manipal have started finding housing in the serene and thinly populated land of Parkala. Nonetheless the growth of building construction in Parkala is very slow. Refer Fig. 5 [19]. Green patch of natural vegetation is still not disturbed much.
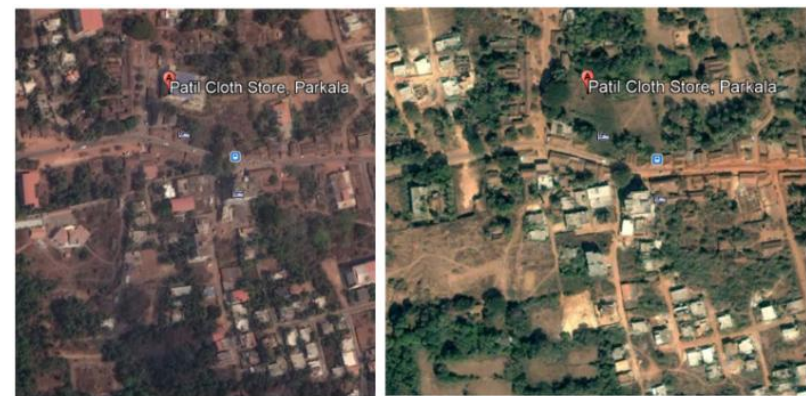

Fig. 5. Satellite Map of Parkala region in the year 2019(left) and 2004 (right)

Published By:

Blue Eyes Intelligence Engineering \& Sciences Publication 
Now to compare the development of Manipal with another town in Udupi district, Kundapura town is taken into consideration which is $39 \mathrm{Km}$. away from Manipal. Kundapura is connected to Udupi by National Highway 17. Kundapura has population density of 254 per sq.km. as per 2011 census which was 238 per sq.km. as per 2001 census. Fig. 6 shows the slow pace of urban sprawl of Kundapura town during the period 2004-2019 [19].
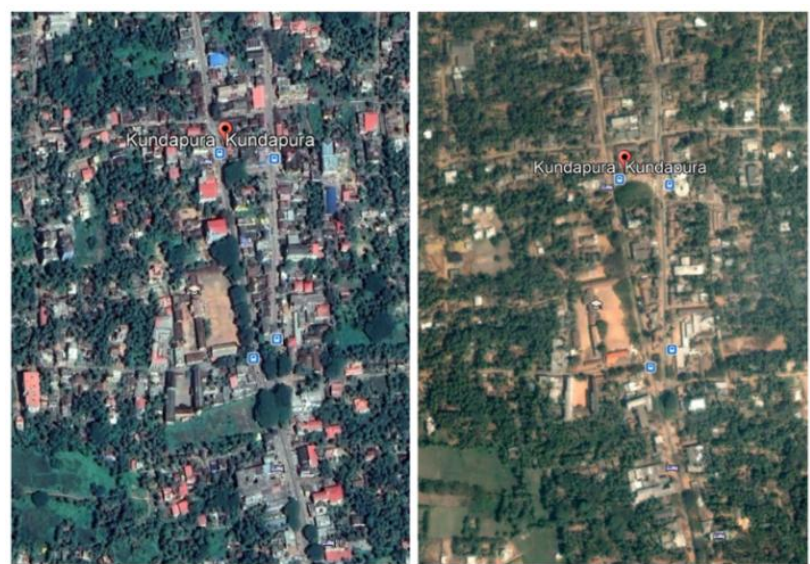

Fig. 6. Satellite Map of Kundapura region on in the year 2019(left) and 2004 (right)

\section{Built up land cover of Manipal}

According to Wikipedia, the total area of Manipal town is 26 Sq.km. The population density in the year 2011 was 1300/sq.km. [20]. As per Census data 2011, the Udupi district as a whole has a population density of 329 per Sq.km. Total area of Udupi is 3582 Sq.km. This shows that Manipal has more population concentration.

In an earlier study of investigation of spatial extent of land use/land cover of Udupi Taluk for three different years 2000, 2006 1nd 2010, it was found that the land cover for built up area was $17.81,85.29$ and 310.45 in sq.km. respectively. Increase in built up land area during 2000-2006 is only 67.48 sq. km. whereas during 2006-2010 is 225.16 sq.km. This particular study states that Shivalli village, in which the major part of the university building now situates, has undergone $30 \%$ increase of built up land in the latter duration (2016-2010) due to the real estate hike in the commercial as well as residential sectors [21]. This is graphically shown in the following bar graph.

\section{Area in sq.km.}

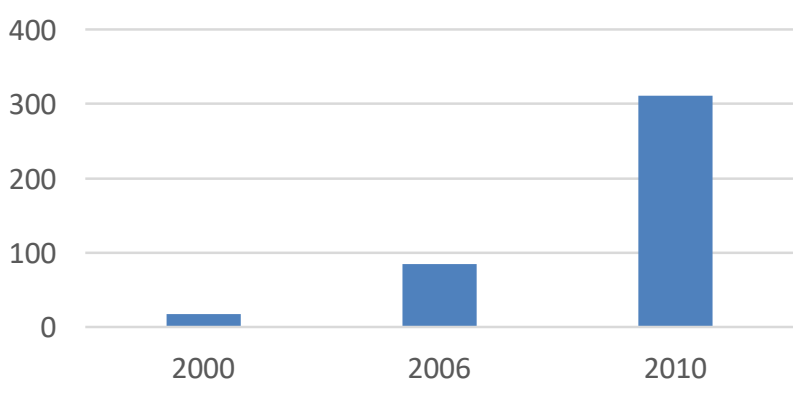

Fig. 7. Bar Graph of Built up Land Area iof Udupi Taluk $n$ the year 2000, 2006 and 2010
Another study conducted in the year 2014, on urban sprawl mapping and land use change detection in and around Udupi town, using remote sensing took data of images in 2003 and 2013 into consideration. It showed drastic increase in the settlement and built up land area during 10 years which was $150.4 \%$ [22].

\section{E. Growth of Real Estate in Manipal}

According to Federation of Indian Chambers of Commerce and Industry, it states that as the business growth and investor realization phase started in 2016, student housing had already been observed as a core real estate asset class as found in Kota (another college town in Rajasthan), Manipal etc. [23].

The rent for housing is found to be almost the same as that in nearby city Mangalore. Almost every apartment in Manipal has been let out for student housing on rental basis. When a rough data of the occupants of houses in Manipal was surveyed above $90 \%$ of the families of dwellers were some way or the other connected with the existence of students and the university through their career at least at some point of their life. Land value of property in Manipal is much high and is almost equivalent or more than that in nearby city, Udupi. Many outsiders from various other states of India as well as from foreign and distant places, keep investing on housing and commercial properties in Manipal because of the increasing prospects.

\section{F. Commercial Growth of Manipal}

The author tries to contemplate the commercial growth of Manipal by enlisting the existing retail shops of various famous brands of apparels, restaurants, multiplex etc.

In 1997, the first multiplex which has high class seating, state of the art screens and audio visual systems was introduced in India. INOX is one of the leading multiplex players and cinema chains [24]. Apart from INOX, Manipal has another multiplex called Bharat Cinemas which has three screens.

There are 2 number of star hotels and around 22 number of high class ordinary hotels and several homestays in Manipal. There are around 56 number of restaurants. Key brands in Quick Service Restaurants such as Subway, Pizza Hut, KFC, Dominos, Barbeque Nation and McDonalds all function in Manipal. The famous brands Cafe Coffee Day which is a casual hang out was opened in 2011. The latest trend is to avail food delivered at the door step with a single click from a series of restaurants. For this, famous chains like Swiggy, Zomato etc. also operate in Manipal.

The $4^{\text {th }}$ and $5^{\text {th }}$ largest shopping malls in Karnataka situate in Mangalore city which are Forum Fiza Mall and City Centre Mall respectively. The retail outlets of famous international brands in various category that exist in Manipal have been compared with those available at the above said commercial malls in Mangalore in Table no. 1.

Many more branded shops like Jan Sports, American Tourister etc. in baggages items; Barista, Baskin Robins, Onesta, Hangyo etc. in the items of food \& beverages are available in Manipal. Many number of supermarkets, 
vegetable and fruit shops, gift shops and flower stalls, dance floors, offices of courier service and travel agents, Syndicate bank head quarters, various highrise apartments, beauty salons etc. give life to Manipal at its full capacity.

Autoriksha stands are there at every $500 \mathrm{~m}$ interval. Many open spaces as parks and lake also exist. Around the
Manipal lake a beautiful walking track and benches create a breathing space to the residents. Transportation connectivity to all the main cities like Mumbai, Bangalore, Hyderabad, Hubli etc. originate from Manipal. Briefly speaking Manipal has grown into a very magnificent city due to the establishment of Manipal Academy of higher Education.

TABLE I PRESENCE OF BRANDED SHOPS IN MANIPAL AVAILABLE AT MALLS IN MANGALORE

\begin{tabular}{|c|l|l|l|}
\hline \multirow{2}{*}{ Category } & \multicolumn{3}{|c|}{ Branded Shops at Manipal } \\
\cline { 2 - 4 } & \multicolumn{1}{|c|}{ Dress Apparels } & \multicolumn{1}{|c|}{ Food \& Beverages } & \multicolumn{1}{c|}{ Others } \\
\hline \multirow{5}{*}{ Name of the brand } & Aurelia, Fab India, Go & & Apple, Archies, Crocs, \\
& Colors, Levis, Louis Philip, & Café Coffe Day, Dominos, & PUMA, Reliance Digital, \\
& Raymond, Soch, Lee, & Hangyo, McDonalds, Pizza & Skechers, VIP, Woodlands, \\
& People, mufti, Fbb, Jockey, & Hut, Baskin Robbins, KFC, & Sangeetha Mobiles, \\
& Van Heusen, Allen Solly, W, & Keventers & ADIDAS, Mochi, Fastrack, \\
& Pepe Jeans & & Wildcraft, \\
\hline
\end{tabular}

\section{SUGGESTION FOR CRITERIA TO DEFINE UNIVERSITY TOWN}

Population which is a factor to measure one University city in the U.S. can not be considered as one in India, since the population density of both the countries differ a lot. The culture and trend of the society in both the countries are different. As the country is still developing, students after graduation try to leave the country to a developed nation in search of better jobs. They seldom like to settle down in the university premises.

But it may be good to suggest that university towns can be measured by certain figure or percentage of the population who directly or indirectly depend on the existence of the university. Also the increase in standard of living, real estate value, migration of population to the town, various amenities of international standard and quality etc. can also be kept as measures to define University Town.

\section{CONCLUSION}

In India the ancient Budhist monastery and the world's first residential center of learning called Nalanda which existed in $400 \mathrm{AD}$ and was not functioning for very many years happened to have revitalized as Nalanda International University in 2014. The reason behind this being nothing but the fact that any University in a country provides development due to the advent of knowledge bank and advancement of research in many fields. This promising phenomenon enables the community of university town behave in an advanced manner along with the pace of positive economic growth.

Innovations have to be sought in terms of architectural intervention of new paradigm of commercial as well as business sectors in university towns which will attract more people to settle down in the town. The total progress will thereby aid the overall economic enhancement of the country.

\section{ACKNOWLEDGMENT}

I am deeply indebted to Manipal Academy of Higher Education, India for giving continuous support and motivation in doing quality research.

\section{REFERENCES}

1. Jaison R. Abel and Richard Deitz, "Do Colleges and Universities Increase Their Region's Human Capital," Current Issues in Economics and Finance, vol. 17, No. 6, available at www.newyorkfed.org/research/current_issues retrieved on 24/03/2019.

2. Gardy, Sean, "The Economics of a College Town", The Park Place Economist, vol. 25, Issue I, Article 12, 2017.available http://digitalcommons.iwu.edu/parkplace/vol25/iss1/12

3. Narendar Pani, "Place of Learning or Piece of Real Estate?," article appeared on 'The Hindu, Businessline' on September 24, 2017.

4. Pujar, Siddaramaiah, "Managing Changes in Indian State Universities with Specific Reference to Universities in Karnataka State", 2004; Ph.D. Thesis available in shodhganga.inflibnet.ac.in.

5. https://whc.unesco.org/en/list/876 as retrieved on $13 / 04 / 2019$.

6. http://censusindia.gov.in/2011-provresults/paper2/data_files/India2/1.\%20Data\%20Highlight.p df retrieved on 10/04/2019.

7. Le Minh Ngo and Tu Anh Trinh, "A University-City Complex, A Model for Sustainable Development: A Case Study in Vietnam", Proceedia Engineering 142, 2016.

8. Luisa Cannas da Silva and Teressa Valsassina Heitor, "Campus as a City, City as a Campus: University Precincts in Urban Context", Proceedings of the 7th knowledge cities world summit, (2014)

9. Gehl, J., "Life Between Buildings: Using Public Space" (transl. by Koch, J) New York Van Norstrand Reinhold, 1987, 2011 revisted ed., pg. 17.

10. Sarcu, Corey et.el, "Social Behaviour in Public Spaces in a College Town”, Sociologija I prostor 50, 2012.

11. Rachael A. Woldoff and Karen G. Weiss, "Studentification and Disorder in a College Town", City and Community, 2018.

12. Jennifer Massey, Sean Field and Yolande Chan, "Partnering for Economic Development: How Town-Gown Relations Impact Local Economic Development in Small and medium Cities", Canadian Journal of Higher Education, Vol. 44, No.2, 2014.

13. Scott Shapiro, "New Species of City Discovered: The University City", unpublished. 
14. "Manipal: How a barron Hillock in Mangalore has Tranformed into a University Town", available at The Economic Times , $11^{\text {th }}$ Dec 2016 //economictimes.indiatimes.com/articleshow/55915833.cm s?utm_source $=$ contentofinterest\&utm_medium =text\&utm campaign=cppst retreived on 20-04-2019.

15. Administrative Atlas, Karnataka available at www.censusindia.gov.in retreived on 20/04/2019.

16. www.google.com/maps/place/Manipal as retreived on 20/04/2019.

17. Manipal Fact sheet available at https://manipal.edu/mu/important-links-manipaluniversity.html as retreived on 20/04/2019.

18. http://muportal/doc.aspx?doc=cms/docs/documents/Facts Figures_MAHE_Nov2018.pdf retrieved on 22/04/2019

19. Satellite Historical map available at https://www.google.earth.com

20. Das, Shilpy and Mohandas Chadaga, "Temporal Variation of Surface and Ground Water Quality in Manipal Region A Case Study", International Journal of Innovative Research in Science, Engineering and Technology, vol.4, issue 6, pp. 4939-4943.

21. Usha, Naveenchandra B., Thukaram M. and Mohandas Chadaga, "The Study of impact of Urbanisation on Urban Heat Island with Temperature Variation Analysis of MODIS Data using Remote Sensing and GIS Technology", International Journal of Avanced Remote Sensing and GIS, 2015, vol.4, issue 1, pp. 944-952.

22. Silambarasan K., M. S. Vinaya and S. Suresh Babu, "Urban Sprawl Mapping and Land Use Change Detection in and around Udupi: A Remote Sensing based Approach", International Journal of Scientific Research Engineering and Technology, 2014, vol.2, issue 12, pp. 815-820.

23. FICCI and JLL - Report on 'Future of India Real Estate: Deciphering the mid-term perspective', September 2018.

24. Sai, Srinivas, V, "Growth of Multiplex and its Impact- An Indian Cinema Experience", available at www.academia.edu retreived on 25/04/2019. 